\title{
EVALUATION THE COACHING PROGRAM OF TENNIS TEAM OF BANGKA BELITUNG PROVINCE IN PON XIX WEST JAVA 2016
}

\author{
Kurnia Tahki ${ }^{1}$, Mulyana ${ }^{2}$, James Tangkudung ${ }^{3}$ \\ State University of Jakarta ${ }^{1}$ \\ State University of Jakarta ${ }^{2}$ \\ State University of Jakarta ${ }^{3}$ \\ Kurniatahki@gmail.com ${ }^{1}$ \\ mulyana@unj.ac.id² \\ jamestangkudung@unj.ac.id
}

\begin{abstract}
Coaching in every sport should be a planned and continuous process so as to achieve the expected goal. A well-developed and executed coaching program is also capable of being evaluated in order to make improvements over time. The purpose of this research is to get information about coaching program of Pelatda's TennisTeam of Bangka Belitung Province in PON XIX West Java 2016. This research was conducted in Jakarta, Bandung and Bangka Belitung from February to December 2016, before and after PON XIX West Java 2016.This evaluation research using qualitative method with evaluation model Context, Input, Process, Product or CIPP according D.Stufflebeam (2002). Data collection was done by interview, observation, documentation study and interactive. Data sources in this research are: Youth and Sports Office of Bangka Belitung Province, KONI of Bangka Belitung Province, coaches of pelatda, PELTI of Bangka Belitung Province.The results concluded that: (1). The evaluation component of context stage is considered sufficient (59.26\%). (2). The evaluation component of input stage is considered sufficient $(65,63 \%)$. (3). The evaluation component of process stages is considered less (42.86\%). (4). The evaluation component of product stage is considered to be very less $(28,58 \%)$.
\end{abstract}

Keywords: $\quad$ Evaluation, Coaching Program, Tennis Team of Bangka Belitung Province, PON XIX West Java 2016

Pekan Olahraga Nasional (PON) is one of the points where athletes and coaches can test and measure each other to what extent they have been carefully prepared, systematically and in various ways and power to be tested in the national sport event. This is because sport is not something that can be created instantly and requires a long process, and planned to get optimal results. Therefore, PON serve as a standard achievement of each sport in measuring the improvement of achievements that have been achieved and is a form of assessment of the coaching process in its area.

PON XIX West Java 2016 became a momentum for the rise of tennis sports in Bangka Belitung. The province of Bangka is able to print history for the first time qualifying Pre-PON for tennis representing Sumatera region, this momentum must be maintained consistenly in the coming years so that the Province of Bangka Belitung able to create the potential seeds of tennis athletes. Consistency is slowly able to create achievements not only at the regional level but at the national and even international level. This is what concern of researcher to see by firsthand about the essential 
aspects of the coaching program of Tennis Team of Bangka Belitung Province in PON XIX West Java 2016.

Evaluation is one part of the management system that is planning, organization, implementation, monitoring and evaluation. Without evaluation, it will not be known how the condition of the evaluation object is in the design, implementation and result. The same thing is presented by R. Lance (2007) which explains that evaluation is usually done with the aim to assess the overall object of evaluation, starting from planning, process and implementation procedures, along with the results.

According to Djaali and Pudji Mujiono (2008), evaluation can also be interpreted as the process of assessing something based on predetermined criteria or objectives followed by decision making on the object being evaluated. According to Leigh Deves (2011) explains that the evaluation process is carried out through an empirical observation or gathering facts, in order to know a value or benefit. In line with Malcolm and Provus in Farida (2006) suggests that evaluation is what differences exist with a standard to see if there is a discrepancy. Similarly, explained by Ann and Paul (2012) that basically the evaluation is to conduct the action of reviewing, analyzing, and then assessing the information about the object being evaluated.

Definition of evaluation according to Arikunto and Cepi (2009), that evaluation is an activity to gather information about the work of something, which then the information is used to determine the right alternative in taking a decision. According to Wirawan (2011) evaluation activities are: research to collect, analyze, and present useful information about the object of evaluation, then assesst and compare it with the evaluation indicator, and the result is used to make decision about the object of evaluation.

Based on the definition of evaluation that has been stated above, evaluation is an activity that compares the results of implementation with the criteria and standards that have been set to see its success. From the evaluation then will be available information about the extent to which a certain activity has been achieved so that it can be known if there is a difference between the standard that has been set with the results that can be achieved.

Definition of program evaluation according to Arikunto and Abdul Jabar (2009) is an effort to know the level of policy's implementation by knowing the effectiveness of each component. Matt Vassar (2010) explains how by collecting information from evaluated programs, then analyzing them and comparing them with predefined standards.

The concept of program evaluation according to Sukardi (2010) argues that: The program evaluation covers a broader subject, can be started from the evaluation of the curriculum to the evaluation of the program in the field of study and the object of program evaluation may also vary including program policies, effectiveness and implementation program. Program evaluation according to Wirawan (2011) is a systematic methods to collect, analyze, and use information to answer basic questions about the program. Program evaluation can be grouped into process evaluation, outcome evaluation and impact evaluation.

Based on the above description, it can be concluded that the evaluation of the program is the activity of collecting, compiling and processing information and analyze it, about whether a program works or not or how far the program has been achieved, so it can be known if there is a discrepancy between the plan that has been established with the results that can be achieved. Further information is used to establish an appropriate alternative or choice in deciding whether the program is stopped, revising the program, continuing the program and disseminating the program.

Sport development programs include development planning of components that can support the growth of potential sports into a superior sport of a region. According to Paul Ford Dkk (2011), development of potential and talented athletes in early age is defined as the main foundation, then coaching must be done systematically, tiered, and sustainable so as to achieve high performance. This 
is in accordance with the opinion of James Tangkudung (2012) that the talented athlete is required a special coaching so that they can manifest their talent optimally, either to develop themselves or to make a meaningful contribution to others.

The first fundamental effort undertaken in sports coaching is to examine the multi aspects as outlined in the mandate of Government Regulation No. 16 of 2007, especially those relating to the sports achievement scope component. These aspects include: (1) Sports Coach, (2) Club or Association, (3) Training / Upgrades, (4) Infrastructure and Facilities, (5) Competition Climate, (6) Championship or competition, (7) Coaching center (8) Sport Science and technology, (9) Information Systems, (10) Funding, and (11) Awards.

Sporting achievement is a final accomplishment achieved based on the initial target of the team or athlete. Achievement of a sport is basically the realization of many interrelated factors, and each has its own contribution / role in achieving the optimal achievement. High achievement, is the result of a series of long training process and done in a planned / systematic, and tiered. So the achievement is not always synonymous with the champion, although not be a champion or get the victory, but if it has been able to meet or even exceed the initial target, then it can already be said achievers.

This research will use CIPP model with four evaluation objectives: Context, Input, Process, and Product. According to Stufflebeam Shinkfield (2007), goal setting creates questions for context evaluation, which in turn provides information to validate or improve goals. Planning for improvement efforts generates questions for input evaluation, which provides an assessment of the plan and direction to strengthen the plan. Program actions creates questions for process evaluation, which provides activity assessment plus feedback to strengthen staff performance. Achievement or lack of achievement is side effects of product evaluation, which ultimately will issue final results decisions and identify the need to achieve better results in the future.

\section{METHOD}

This study uses an approach that refers to the CIPP model with four evaluation objectives (Context, Input, Process, and Product). This CIPP model as a guidance in classifying and analyzing evaluation of coaching program of Tennis Team of Bangka Belitung Province on PON XIX West Java 2016. The research method used in this research using qualitative research methods. Data collection procedures through interviews, observation, and documentation. The examination of the validity of the data is carried out through of diligence researcher's observation, triangulation and peer examination through discussion. Analysis of research data is done by the procedure as follows: 1) Data reduction 2) Presentation of data and 3) Conclusion.

Table 1. Grid Instrument in Evaluation The Coaching Program of Tennis Team of Bangka Belitung Province in PON XIX 2016

\begin{tabular}{|c|c|c|c|c|}
\hline No & Aspect of Evaluation & Indicator & $\begin{array}{l}\text { Number } \\
\text { of Item }\end{array}$ & $\begin{array}{c}\text { Total of } \\
\text { Item }\end{array}$ \\
\hline \multirow[t]{2}{*}{1} & \multirow[t]{2}{*}{ Context (Planning) } & 1. Goals & $1-4$ & \multirow[t]{2}{*}{9} \\
\hline & & 2. Planning strategy & $1-5$ & \\
\hline \multirow[t]{3}{*}{2} & \multirow[t]{3}{*}{ Input (Organization) } & 1. Condition of Athlete & $1-3$ & \multirow[t]{3}{*}{11} \\
\hline & & 2. Condition of Coach & $1-4$ & \\
\hline & & 3. Support of Agency & $1-4$ & \\
\hline \multirow[t]{2}{*}{3} & \multirow[t]{2}{*}{ Process (Implementation) } & 1. Implementation of Coaching & $1-4$ & \multirow[t]{2}{*}{7} \\
\hline & & 2. Training Programme & $1-3$ & \\
\hline 4 & Product (Result) & $\begin{array}{l}\text { 1. Individual result in PON } \\
\text { 2. Group result in PON }\end{array}$ & $\begin{array}{l}1-5 \\
1-2\end{array}$ & 7 \\
\hline & & & & 34 \\
\hline
\end{tabular}




\section{Component of Context}

\section{RESULT}

Implementation of context's component in the coaching program of Tennis Team of Bangka Belitung Province in PON XIX West Java 2016 includes: the goals and planning strategy of the coaching program of Tennis Team of Bangka Belitung Province in PON XIX West Java 2016. For the goals of the coaching program of Tennis Team of Bangka Belitung Province in PON XIX West Java 2016 can be seen in the following table:

Table 2. Goals of Coaching Program of Tennis Team of Bangka Belitung Province in PON XIX West Java 2016.

\begin{tabular}{|c|c|c|c|c|}
\hline \multirow[t]{2}{*}{ No } & \multirow[t]{2}{*}{ Aspects of of the Assessment } & \multicolumn{2}{|c|}{$\begin{array}{c}\text { Evaluation } \\
\text { Result }\end{array}$} & \multirow[t]{2}{*}{ Information } \\
\hline & & Yes & No & \\
\hline 1 & $\begin{array}{l}\text { Programs goals have been classified into short, } \\
\text { medium and long term coaching programs. }\end{array}$ & $\sqrt{ }$ & & \\
\hline 2 & $\begin{array}{l}\text { The coaching program implemented has a clear } \\
\text { vision. }\end{array}$ & $\sqrt{ }$ & & \\
\hline 3 & $\begin{array}{l}\text { The coaching program that has been } \\
\text { implemented already has a clear mission. }\end{array}$ & $\sqrt{ }$ & & \\
\hline 4. & $\begin{array}{l}\text { Goal targets are clearly defined based on the } \\
\text { featured sports number. }\end{array}$ & & $\sqrt{ }$ & $\begin{array}{lr}\text { Limited } & \text { existing } \\
\text { athletes } & \text { making } \\
\text { difficult } & \text { to } \\
\text { determine } & \text { the } \\
\text { leading } & \text { sports } \\
\text { number. } & \end{array}$ \\
\hline
\end{tabular}

Meanwhile, for planning strategy of the coaching program of Tennis Team of Bangka Belitung Province in PON XIX West Java 2016 consist of: organization, procedur of athlete's recruitment, procedure of coach's recruitment, availability of facilities and infrastructure, and availability of financing. All these results can be seen in the following table:

Table 3. Organization of Tennis Team of Bangka Belitung Province

in PON XIX West Java 2016

\begin{tabular}{|c|c|c|c|c|}
\hline \multirow[t]{2}{*}{ No } & \multirow[t]{2}{*}{ Aspects of of the Assessment } & \multicolumn{2}{|c|}{$\begin{array}{c}\text { Evaluation } \\
\text { Result }\end{array}$} & \multirow[t]{2}{*}{ Information } \\
\hline & & Yes & No & \\
\hline 1 & $\begin{array}{l}\text { SK organizing about coaching program of } \\
\text { Tennis Team of Bangka Belitung Province in } \\
\text { PON XIX West Java2016. }\end{array}$ & $\sqrt{ }$ & & \\
\hline 2 & $\begin{array}{l}\text { Organizational structure about coaching of } \\
\text { Tennis Team of Bangka Belitung Province in } \\
\text { PON XIX West Java } 2016 \text {. } \\
\text { Guidelines for coaching program of Tennis } \\
\text { Team of Bangka Belitung Province in PON } \\
\text { XIX West Java 2016. }\end{array}$ & $\sqrt{ }$ & $\sqrt{ }$ & \\
\hline
\end{tabular}


Table 4. Procedures of Athletes' Recruitment in Tennis Team of Bangka Belitung Province in PON XIX West Java 2016

\begin{tabular}{|c|l|c|c|c|}
\hline \multirow{2}{*}{ No } & \multicolumn{1}{|c|}{ Aspects of of the Assessment } & \multicolumn{2}{c|}{$\begin{array}{c}\text { Evaluation } \\
\text { Result }\end{array}$} & \multirow{2}{*}{ Information } \\
\cline { 3 - 4 } & & Yes & No & \\
\hline 1 & Meets the criteria of U-21 age & $\sqrt{ }$ & & \\
2 & Minimal achivement as local athletes & $\sqrt{ }$ & \\
3 & Undergo a physical test selection & & $\sqrt{ }$ & \\
4 & Undergo the selection of skills tests & & $\sqrt{ }$ & \\
5 & Undergo the selection of medical tests & & $\sqrt{ }$ & \\
6 & Undergo the selection of psychological tests & & $\sqrt{ }$ & \\
7 & Not involved in crime and drug abuse & $\sqrt{ }$ & & \\
8 & Got recommendation from PELTI of Province & $\sqrt{ }$ & & \\
& & & & \\
\hline
\end{tabular}

Table 5. Procedures of Coach's Recruitment in Tennis Team of Bangka Belitung Province in PON XIX West Java 2016

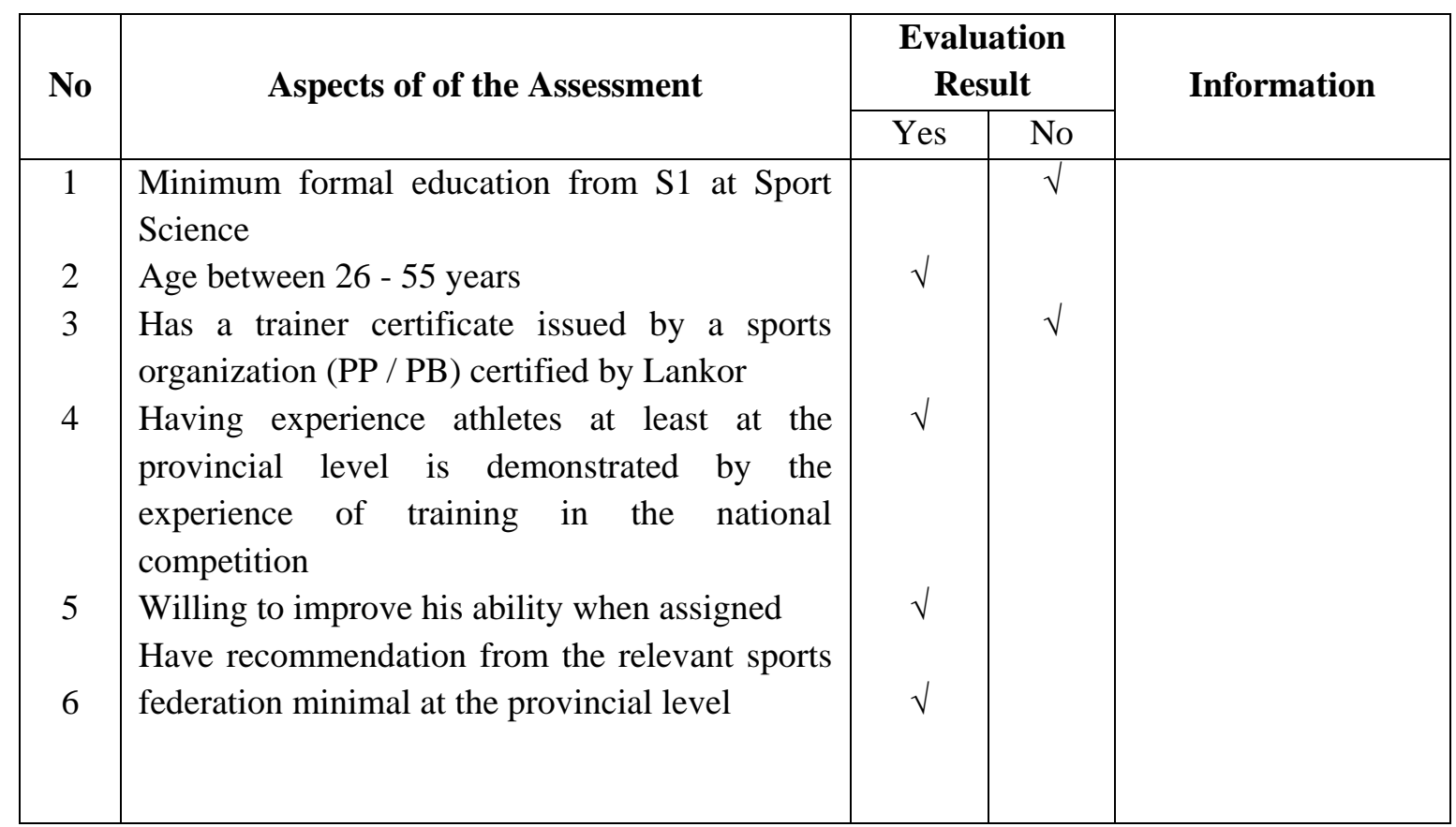

Table 6. Availability of Facilities and Infrastructure in the Coaching Program of Tennis Team of Bangka Belitung Province in PON XIX West Java 2016

\begin{tabular}{|c|c|c|c|c|}
\hline \multirow[t]{2}{*}{ No } & \multirow[t]{2}{*}{ Aspects of of the Assessment } & \multicolumn{2}{|c|}{$\begin{array}{c}\text { Evaluation } \\
\text { Result }\end{array}$} & \multirow[t]{2}{*}{ Information } \\
\hline & & Yes & No & \\
\hline 1 & $\begin{array}{l}\text { Availability and feasibility of } \\
\text { dormitory/residence }\end{array}$ & $\sqrt{ }$ & & \\
\hline 2 & $\begin{array}{l}\text { Availability and feasibility of training ground } \\
\text { Availability and feasibility of training } \\
\text { equipment }\end{array}$ & $\sqrt{ }$ & $\sqrt{ }$ & \\
\hline
\end{tabular}




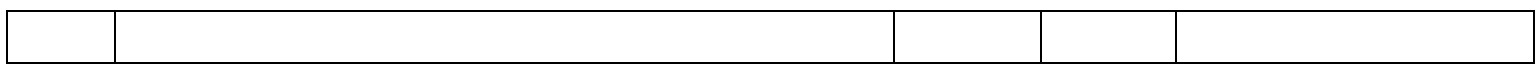

Table 7. Availability of Financing in the Coaching Program of Tennis Team of Bangka Belitung Province in PON XIX West Java 2016.

\begin{tabular}{|c|l|c|c|c|}
\hline \multirow{2}{*}{ No } & \multicolumn{1}{|c|}{ Aspects of of the Assessment } & \multicolumn{2}{|c|}{$\begin{array}{c}\text { Evaluation } \\
\text { Result }\end{array}$} & \multirow{2}{*}{ Information } \\
\cline { 3 - 4 } & \multicolumn{1}{|c|}{$\begin{array}{c}\text { Yes } \\
\text { No }\end{array}$} & \\
\hline 1 & $\begin{array}{l}\text { Local Goverment (Anggaran Pendapatan dan } \\
\text { Belanja Negara/APBD) } \\
\text { Other non-binding sources (Donors) }\end{array}$ & $\sqrt{ }$ & $\sqrt{ }$ & \\
& $\begin{array}{l}\text { Club financing originating from other sources } \\
\text { (sponsor) }\end{array}$ & $\sqrt{ }$ & \\
\hline
\end{tabular}

Based on the overall evaluation of the context that includes the goals and planning strategy in coaching program of Tennis Team of Bangka Belitung Province in PON XIX West Java 2016, from 27 aspects of the assessment obtained an average score of 59.26\%. Overall, with an average score of $59.26 \%$ indicates that the evaluation of the context in Coaching Program of Tennis Team of the Bangka Belitung Province in PON XIX West Java 2016 is included in the category of sufficient (56\% $-65 \%)$.

\section{Component of Input}

Implementation of input's component in the coaching program of Tennis Team of Bangka Belitung Province in PON XIX West Java 2016 include: a) Condition of athletes, b) Condition of Coach, and c) Support of Agency. Here is an evaluation on the input component of the Coaching Program of Tennis Team of Bangka Belitung Province in PON XIX West Java 2016.

a) Condition of Athletes

Condition of athetes in coaching program of Tennis Team of Bangka Belitung Province for PON XIX West Java 2016 consist of: qualification of athletes, facilities of athletes, and welfare of athletes. All these results can be seen in the following table:

Table 8. Qualification of Athletes in Coaching of Tennis Team of Bangka Belitung Province in PON XIX West Java 2016

\begin{tabular}{|c|l|c|c|c|}
\hline \multirow{2}{*}{ No } & \multicolumn{1}{|c|}{ Aspects of of the Assessment } & \multicolumn{2}{c|}{$\begin{array}{c}\text { Evaluation } \\
\text { Result }\end{array}$} & \multirow{2}{*}{ Information } \\
\cline { 3 - 4 } & & \multicolumn{1}{|c|}{ Yes } & No & \\
\hline 1 & Meet the age criteria & $\sqrt{ }$ & & \\
3 & Get recommendations from PELTI Province & $\sqrt{ }$ & & \\
& Physically fit the body & & & \\
& Meet qualifications of pusture (anthropometric) & $\sqrt{ }$ & & \\
4 & Meet the criteria for tennis skills & Meet the standard of physical capacity & $\sqrt{ }$ & \\
5 & Meet the criteria of psychology & & $\sqrt{ }$ & \\
6 & Meet the criteria of health & & $\sqrt{ }$ & \\
7 & & & $\sqrt{ }$ & \\
\hline
\end{tabular}


Table 9. Facilities of Athlete in Coaching Program of Tennis Team of Bangka Belitung Province in PON XIX West Java 2016

\begin{tabular}{|c|l|c|c|c|}
\hline \multirow{2}{*}{ No } & \multicolumn{1}{|c|}{ Aspects of of the Assessment } & \multicolumn{2}{c|}{$\begin{array}{c}\text { Evaluation } \\
\text { Result }\end{array}$} & \multirow{2}{*}{ Information } \\
\cline { 3 - 4 } & & Yes & No & \\
\hline 1 & Dormitory/Residence & $\sqrt{ }$ & & \\
2 & Training equipment & $\sqrt{ }$ & & \\
3 & Match equipment & $\sqrt{ }$ & & \\
4 & Medical and health services for athletes & & $\sqrt{ }$ & \\
5 & Sport Psychology services for athletes & & $\sqrt{ }$ & \\
\hline
\end{tabular}

Table 10. Welfare of Athlete in Coaching Program of Tennis Team of Bangka Belitung Province in PON XIX West Java 2016

\begin{tabular}{|c|c|c|c|c|}
\hline \multirow[t]{2}{*}{ No } & \multirow[t]{2}{*}{ Aspects of of the Assessment } & \multicolumn{2}{|c|}{$\begin{array}{c}\text { Evaluation } \\
\text { Result }\end{array}$} & \multirow[t]{2}{*}{ Information } \\
\hline & & Yes & No & \\
\hline 1 & Pocket money & $\sqrt{ }$ & & \\
\hline 2 & Transport money & $\sqrt{ }$ & & \\
\hline 3 & Bonus & & $\sqrt{ }$ & \\
\hline
\end{tabular}

b) Condition of Coaches

Condition of coach in coaching program of Tennis Team of Bangka Belitung Province for PON XIX West Java 2016 consist of: qualification of coaches, achievement of coaches, facilities of coaches, and welfare of coaches. All these results can be seen in the following table:

Table 11. Qualification of Coaches in Coaching Program of Tennis Team of Bangka Belitung Province in PON XIX West Java 2016

\begin{tabular}{|c|c|c|c|c|}
\hline \multirow[t]{2}{*}{ No } & \multirow[t]{2}{*}{ Aspects of of the Assessment } & \multicolumn{2}{|c|}{$\begin{array}{c}\text { Evaluation } \\
\text { Result }\end{array}$} & \multirow[t]{2}{*}{ Information } \\
\hline & & Yes & No & \\
\hline 1 & Education & & $\sqrt{ }$ & \\
\hline 2 & Coaching Skills & $\sqrt{ }$ & & \\
\hline 3 & Experiences & $\sqrt{ }$ & & \\
\hline
\end{tabular}

Table 12. Achievement of Coaches in Coaching Program of Tennis Team of Bangka Belitung Province in PON XIX West Java 2016

\begin{tabular}{|l|l|c|c|c|}
\hline \multirow{2}{*}{ No } & \multirow{2}{*}{ Aspects of of the Assessment } & \multicolumn{2}{|c|}{$\begin{array}{c}\text { Evaluation } \\
\text { Result }\end{array}$} & \multirow{2}{*}{ Information } \\
\cline { 3 - 3 } & & Yes & No & \\
\hline
\end{tabular}




\begin{tabular}{|l|l|r|r|r|}
\hline 1 & Regional & $\sqrt{ }$ & & \\
2 & Province & $\sqrt{ }$ & & \\
3 & National & & $\sqrt{ }$ & \\
4 & International & & $\sqrt{ }$ & \\
\hline
\end{tabular}

Table 13. Facilities of Coaches in Coaching Program of Tennis Team of Bangka Belitung Province in PON XIX West Java 2016

\begin{tabular}{|c|l|c|c|c|}
\hline \multirow{2}{*}{ No } & \multicolumn{1}{|c|}{ Aspects of of the Assessment } & \multicolumn{2}{c|}{$\begin{array}{c}\text { Evaluation } \\
\text { Result }\end{array}$} & \multirow{2}{*}{ Information } \\
\cline { 3 - 4 } & & Yes & No & \\
\hline 1 & Dormitory/Residence & $\sqrt{ }$ & \multirow{2}{*}{$\sqrt{ }$} \\
2 & Coaching equipment & $\sqrt{ }$ & & \\
3 & Coach's equipment & $\sqrt{ }$ & \\
\hline
\end{tabular}

Table 14. Welfare of Coaches in Coaching Program of Tennis Team of Bangka Belitung Province in PON XIX West Java 2016

\begin{tabular}{|c|l|c|c|c|}
\hline \multirow{2}{*}{ No } & \multicolumn{1}{|c|}{ Aspects of of the Assessment } & \multicolumn{2}{|c|}{$\begin{array}{c}\text { Evaluation } \\
\text { Result }\end{array}$} & \multirow{2}{*}{ Information } \\
\cline { 3 - 4 } & & Yes & No & \\
\hline 1 & Pocket money & $\sqrt{ }$ & & \\
2 & Transport money & $\sqrt{ }$ & \\
3 & Bonus & & $\sqrt{ }$ & \\
\hline
\end{tabular}

c) Supprt of Agency

Table 15. Support of Agency in Coaching Program of Tennis Team of Bangka Belitung Province in PON XIX West Java 2016

\begin{tabular}{|c|c|c|c|c|}
\hline \multirow[t]{2}{*}{ No } & \multirow[t]{2}{*}{ Aspects of of the Assessment } & \multicolumn{2}{|c|}{$\begin{array}{c}\text { Evaluation } \\
\text { Result }\end{array}$} & \multirow[t]{2}{*}{ Information } \\
\hline & & Yes & $\mathrm{No}$ & \\
\hline 1 & Youth and Sport Office & $\sqrt{ }$ & & \\
\hline 2 & KONI of Province & $\sqrt{ }$ & & \\
\hline 3 & PELTI of Province & $\sqrt{ }$ & & \\
\hline 4 & Parents & $\sqrt{ }$ & & \\
\hline
\end{tabular}

Based on the overall evaluation of inputs which include condition of athletes, condition of coach, and support of agency, Coaching Program of Tennis Team of Bangka Belitung Province in PON XIX West Java 2016 from 32 aspect of appraisal got average value 65,63\%. Overall, with an average score of $65.63 \%$ indicates that the evaluation of the input program of in coaching program of Tennis Team of Bangka Belitung Province in PON XIX West Java 2016 included in the category enough $(56 \%-65 \%)$.

\section{Component of Process}


Implementation of process' component in the coaching program of Tennis Team of Bangka Belitung Province in PON XIX West Java 2016 includes: implementation of coaching program and implementation of training program. For implementation of coaching program of Tennis Team of Bangka Belitung Province in PON XIX West Java 2016 can be seen in the following table:

Table 16. Coaching Program System of Tennis Team of Bangka Belitung Province in PON XIX West Java 2016

\begin{tabular}{|c|l|c|c|c|}
\hline \multirow{2}{*}{ No } & \multicolumn{1}{|c|}{ Aspects of of the Assessment } & \multicolumn{2}{c|}{$\begin{array}{c}\text { Evaluation } \\
\text { Result }\end{array}$} & \multirow{2}{*}{ Information } \\
\cline { 3 - 4 } & & Yes & No & \\
\hline 1 & Promotion of athletes & & $\sqrt{ }$ & \\
2 & Degradation of athletes & & $\sqrt{ }$ & \\
3 & Promotion of coaches & & $\sqrt{ }$ & \\
4 & Degradation of coaches & & $\sqrt{ }$ & \\
\hline
\end{tabular}

Meanwhile, for implementation of training program in the coaching program of Tennis Team of Bangka Belitung Province in PON XIX West Java 2016 consist of: training program, try out, and competition. All these results can be seen in the following table:

Table 17. Training Program in The Coaching Program of Tennis Team of Bangka Belitung Province in PON XIX West Java 2016

\begin{tabular}{|c|c|c|c|c|}
\hline \multirow[t]{2}{*}{ No } & \multirow[t]{2}{*}{ Aspects of of the Assessment } & \multicolumn{2}{|c|}{$\begin{array}{l}\text { Evaluation } \\
\text { Result }\end{array}$} & \multirow[t]{2}{*}{ Information } \\
\hline & & Yes & No & \\
\hline 1 & Annual training program & $\sqrt{ }$ & & \\
\hline 2 & Monthly training program & $\sqrt{ }$ & & \\
\hline 3 & Weekly training program & $\sqrt{ }$ & & \\
\hline 4 & $\begin{array}{l}\text { Sport Science and Technology/ IPTEK } \\
\text { application (test - evaluation) }\end{array}$ & & $\sqrt{ }$ & \\
\hline 5 & Progress report of achievment & $\sqrt{ }$ & & \\
\hline
\end{tabular}

Table 18. Try out in The Coaching Program of Tennis Team of Bangka Belitung Province in PON XIX West Java 2016

\begin{tabular}{|c|c|c|c|c|}
\hline \multirow[t]{2}{*}{ No } & \multirow[t]{2}{*}{ Aspects of of the Assessment } & \multicolumn{2}{|c|}{$\begin{array}{c}\text { Evaluation } \\
\text { Result }\end{array}$} & \multirow{2}{*}{ Information } \\
\hline & & Yes & No & \\
\hline 1 & Try in & I & $\sqrt{ }$ & \\
\hline 2 & Try out & v & & \\
\hline
\end{tabular}

Table 19. Competition in The Coaching Program of Pelatda's Tennis Team of Bangka Belitung Province in PON XIX West Java 2016

\begin{tabular}{|c|l|c|c|c|}
\hline \multirow{2}{*}{ No } & \multicolumn{1}{|c|}{ Aspects of of the Assessment } & \multicolumn{2}{c|}{$\begin{array}{c}\text { Evaluation } \\
\text { Result }\end{array}$} & \multirow{2}{*}{ Information } \\
\cline { 3 - 4 } & & Yes & No & \\
\hline 1 & National Championship & & $\sqrt{ }$ & \\
2 & Super Series & $\sqrt{ }$ & \\
3 & Other championships & $\sqrt{ }$ & & \\
\hline
\end{tabular}


Based on the overall result of process evaluation which include implementation of coaching program and implementation of training program in Tennis Team of Bangka Belitung Province in PON XIX West Java 2016, from 14 aspect of appraisal is got average value 42,86\%. Overall, with an average score of $42.86 \%$ indicates that the evaluation process of the coaching program of Tennis Team of Bangka Belitung Province in PON XIX West Java Year 2016 including less category (40\% $55 \%)$.

\section{Component of Product}

Implementation of product' in the coaching program of Tennis Team of Bangka Belitung Province in PON XIX West Java 2016 includes: individual result and team result. For implementation of individual result in coaching program of Tennis Team of Bangka Belitung Province in PON XIX West Java 2016 can be seen in the following table:

Table 20. Individual Result in Coaching Program of Tennis Team of Bangka Belitung Province in PON XIX West Java 2016

\begin{tabular}{|c|l|c|c|c|}
\hline \multirow{2}{*}{ No } & \multicolumn{1}{|c|}{ Aspects of of the Assessment } & \multicolumn{2}{c|}{$\begin{array}{c}\text { Evaluation } \\
\text { Result }\end{array}$} & \multirow{2}{*}{ Information } \\
\cline { 3 - 4 } & \multicolumn{1}{|c|}{ Yes } & No & \\
\hline 1 & Result of singles's men & & & \\
2 & Result of singles's women & & & \\
3 & Result of double's men & & & \\
4 & Result of double's women & & & \\
5 & Result of double's mix & & & \\
\hline
\end{tabular}

Meanwhile, for implementation of team result in the coaching program of Tennis Team of Bangka Belitung Province in PON XIX West Java 2016 can be seen in the following table:

Table 21. Team Result in Coaching Program of Tennis Team of Bangka Belitung Province in PON XIX West Java 2016

\begin{tabular}{|c|c|c|c|c|}
\hline \multirow[t]{2}{*}{ No } & \multirow[t]{2}{*}{ Aspects of of the Assessment } & \multicolumn{2}{|c|}{$\begin{array}{c}\text { Evaluation } \\
\text { Result }\end{array}$} & \multirow[t]{2}{*}{ Information } \\
\hline & & Yes & No & \\
\hline 1 & Result of men's team & & $\sqrt{ }$ & \\
\hline 2 & Result of women's team & & $\sqrt{ }$ & \\
\hline
\end{tabular}

Product evaluation is as the result of implementation in coaching and training program. Based on overall result of product evaluation which includes individual and team result in Coaching Program of Tennis Team of Bangka Belitung Province in PON XIX West Java 2016, from 7 aspects of the assessment obtained an average value of $28.58 \%$. Overall, with an average score of $28.58 \%$ indicates that the product evaluation in coaching program of Tennis Team of Bangka Belitung Province in PON XIX West Java 2016 included into the category is very less (- 40\%). So it can be concluded that the evaluation of product's component is still considered very less in the implementation of coaching and training program of Tennis Team of Bangka Belitung Province in 
PON XIX West Java 2016 because they only got winning or score points in the first round for only individual number (men's singles and men's doubles). While on the team number, Tennis Team of Bangka Belitung Province in PON XIX West Java 2016 did not got the score points anyone. This is partly influenced by non-technical factors, such as unlucky in drawing that they directly meeting the leading teams like East Java Team and West Java Team at the first time.

\section{DISCUSSION}

1. Component of Context in The Coaching Program of Tennis Team of Bangka Belitung Province in PON XIX West Java 2016

a) Goals of The Coaching Program of Tennis Team of Bangka Belitung Province in PON XIX West Java 2016

The result of context component shows that the purpose of coaching program of Tennis Team of Bangka Belitung Province in PON XIX West Java 2016 obtained average value of $75 \%$ including into good category $(66 \%-79 \%)$. Some of the record of the researcher related to the goal of coaching that has not been done is the target achievement is still not clearly compiled based on the number of flagship sports. One of the obstacles of weak target achievement is because the quota of athletes who entered the coaching program of Tennis Team only amounted to 4 athletes. The ability of these four athletes is not evenly distributed, so that becomes an obstacle in achieving the target, especially in the men's team.

Determination of goals in the beginning that only targeted qualifying pass Pre PON makes an obstacle in goal setting that felt only as a short-term goal. As for PON only targets the entrance to the top 8, this is indirectly disrupt the preparation of Tennis Team of Bangka Belitung Province Island Province in the face of PON XIX West Java 2016. The objectives of the coaching program should be classified into short-term, medium and long term coaching program long so that the planning is arranged more systematic and tiered. This is because the Tennis Team of Bangka Belitung Province who has tiered coaching at each level should be the achievement of PON to be a barometer for the highest achievement of athletes from tennis coaching in Bangka Belitung Province.

Coaching program of Pelatda's Bangka Belitung Province has been arranged systematically and tiered. One of the main objectives of coaching program of pelatda 's had been implemented is the achievement or target of five gold medals and the top 20 nationally.

b) Strategy Planning of Coaching Program of Tennis Team of Bangka Belitung Province in PON XIX West Java 2016

Context component related to planning strategy of Tennis Team of Bangka Belitung Province obtained average value equal to $56,52 \%$. Overall, with an average score of $56.52 \%$ indicates that the planning strategy of the coaching program of Tennis Team of Bangka Belitung Province in PON XIX West Java 2016 is included in the category of sufficient $(56 \%-65 \%)$. One aspect that has not been fulfilled in the organization of coaching program of Tennis Team of Bangka Belitung Province in PON XIX West Java 2016 is the absence of guidelines for the coaching program implementation of Tennis Team of Bangka Belitung Province in PON XIX West Java 2016. Guidelines here should be there because this is a guideline and signs of Tennis Team of Bangka Belitung Province in the face of PON XIX West Java 2016.

Procedures for athletes' recruitment and election of Tennis Team of Bangka Belitung Province in PON XIX West Java 2016 is also an important part in planning strategy before coaching goes. The quality of potential and talented athletes is certainly obtained can not be separated from good 
recruitment procedures. The recruitment process still uses an old system that is only selected from the results of the regional championship and the Pengprov recommendations, has not used sport science approaches such as the selection of physical tests, skills tests, medical and psychological tests. This certainly has an impact on the quality of athletes who are not evenly distributed.

The process that has not been going well is the process of coaches' recruitment and election in coaching program of Tennis Team of Bangka Belitung Province in PON XIX West Java 2016. The elected coaches are not educated formal from S1 Sport Science but have a certificate as coach issued by the organization of sports (PP / PB) certified by Lankor (Lembaga Akreditasi Nasional Keolahragaan). The appointed and selected coaches should have experience in handling minimal athletes at the provincial level as well as having recommendations from the sports organization.

Capacity of facilities and infrastructure that exist in coaching program of Tennis Team of Bangka Belitung Province in PON XIX West Java 2016 obtained good results. This is based on two aspects that have been met, namely: availability and feasibility of dormitory / residence as Training Centre (TC), availability and feasibility place of practice. Unfulfilled aspects are the availability and feasibility of practice equipment. The lack of budget in the coaching program of Tennis Team of Bangka Belitung Province resulted a problem in the availability and feasibility of practice equipment that often occurs in the Tennis Team of Bangka Belitung Province.

The capacity of financing in the coaching program of Pelatda's Tennis Team of Bangka Belitung Province in PON XIX West Java 2016 itself is still centered on Local Government Budget or APBD (Anggaran Pendapatan dan Belanja Daerah), no source of financing either from donors or sponsors come from other sources. Overcoming the lack of financing in the coaching program of Tennis Team in Bangka Belitung Province, the local government through the Office of Youth and Sports should in cooperation with local companies to participate in the success of the coaching program Pelatda's Team.

The evaluation of coaching program goals of Tennis Team of Bangka Belitung Province in PON XIX West Java 2016 has been running well. This is in accordance with Stufflebeam's opinion in Sanusi et al (2009) mentions that context evaluation to serve planning decision. This context evaluation helps plan decisions, determines the needs to be achieved by the program, and the formulation of program objectives or goals.

The result of planning strategy evaluation of Tennis Team of Bangka Belitung Province in PON XIX West Java 2016 still need to be improved again for next program. According to Syarifudin (2011), the requirements of planning as follows: 1) objectives must be clearly defined, planning should be simple and realistic; 2) planning includes analyzes and explanations of the planned steps and efforts; 3) efficient and effective in the use of human, financial and facilities.

2. Component of Input in Coaching Program of Tennis Team of Bangka Belitung Province in PON XIX West Java 2016

a) Condition of Athletes in Tennis Team of Bangka Belitung Province in PON XIX West Java 2016

The description of the research about athletes' condition obtained an average value of $60 \%$. Overall, with an average score of $60 \%$ indicates that athletes' condition in coaching program of tennis teams of Bangka Belitung Province on PON XIX West Java 2016 is included in the category of sufficient $(56 \%-65 \%)$.

Based on researcher's of observations about quality of athletes in Tennis Team of Bangka Belitung Province, age of the athletes in Tennis Team in Bangka Belitung Province is still young, so they can can still participate for PON 2020. Two athletes of Tennis Team of Bangka 
Belitung Province have a good ability. They are able to compete with other PON regional athletes. Even at the tennis events that followed, they were able to beat the experienced athletes. Aspects of assessment are less related to the athlete's condition in the coaching program of Tennis Team of Bangka Belitung Province in PON XIX West Java 2016 is: not yet meet the standard of physical capacity. This is because the physical trainer has not been implemented in the training program of Pelatda of Bangka Belitung Province. Psychological and health qualities are also noted in the condition of athletes of Tennis Team. The absence of sport psychologist and medical team assistance makes the athlete's condition decline.

Athletes of Tennis Team in Bangka Belitung Province is a young athlete, which from the psychological aspect has not had a maturity either in attitude or in the face of big games. Therefore, sport psychology's services are needed in the future athletes assistance. In addition to sport psychology's services, sport health services during the Pelatda's Tennis coaching program becomes a note because as health services support successful athletes in implementing the program. The absence of control over the quality of food, vitamins and supplements makes athletes less developed. Even the dangerous thing, the absence of medical team assistance resulted in many athletes who started getting caught doping cases. Sport psychology and health services are a form of facilities that should be provided to athletes as well as residence during TC, training equipment and match equipment. Based on research, sthletes' welfare of Tennis Team Bangka Belitung Province only get pocket and transport money. Bonus awarded only to athletes who won medals. Bonus medal bonus provision itself is still in the process of preparing Governor Regulation not yet legalized.

b) Condition of Coaches in Tennis Team of Bangka Belitung Province in PON XIX West Java 2016

The coaches' condition in Coaching Program of Tennis Team of Bangka Belitung Province in PON XIX West Java Year 2016 obtained an average value of 61.54\%. Overall, with an average score of $61.54 \%$ indicates that the condition of the coaches in the coaching program of Tennis Team of Bangka Belitung Province in PON XIX West Java 2016 is sufficient category (56\% $65 \%)$.

Qualification of coaches who have not met the education criteria for the coaching program of Tennis Team of Bangka Belitung Province in PON XIX West Java 2016. In terms of education, the coach is not a sporting scholar (not graduate from sport science faculty). While from the coach aspect, the coaches have the experience of coaching and already have a license or certification level one. Thus, the coach is expected to have a pretty good skill although still using a conventional approach. One of the basic things is the lack of human resources for tennis coaches in Bangka Belitung Province.

While the coach's achievement of Tennis Team of Bangka Belitung Province on PON XIX West Java Year 2016 still at the regional level, not yet have a national achievement. To overcome this problem, Tennis Team of Bangka Belitung Province for facing PON XIX West Java 2016 do their training centre in Jakarta with the help of existing national coaches. Besides the lack of achievement of coaches, the obstacle is the lack of training equipment that is supportive in implementing the training program. Lack of equipment happened because the fund of Pelatda's PON XIX can only be distributed in July 2016. Based on the research, coaches of Pelatda Tennis Team of Bangka Belitung Province only get pocket and transport money for their welfare. Bonus is not given, because there is no medal obtained on PON XIX West Java 2016.

c) Support of Agency in Tennis Team of Bangka Belitung Province in PON XIX West Java 2016 
Support from related agency in coaching program of Tennis Teams of Bangka Belitung Province in PON XIX West Java 2016 obtained 100\% value. Overall, with an average score of 100\% indicates that the support of related agency in the coaching program of Tennis Team of Bangka Belitung Province in PON XIX West Java 2016 is included in the very good category (80\% $100 \%$ ). This is based on four aspects that have been met namely the support of the Office of Youth and Sports, KONI of Bangka Belitung Province, PELTI of Province and Parents.

Especially local government strongly supports the coaching Program of Tennis Team of Bangka Belitung Province on PON XIX West Java 2016, a form of support provided in terms of budget for pelatda's PON XIX West Java 2016 and aid sports facilities and infrastructure. The form of support from KONI of Bangka Belitung Province is as Pelatda program implementer of course to try as much as possible in running pelatda program. PELTI of Bangka Belitung Province in addition to conducting guidance in the region, participate and provide support through cooperation with private or sponsor in supporting the Pelatda's program. Support from athlete's parents, accompaniment during pelatda program, also witnessed the match of PON XIX West Java 2016.

The results of the overall evaluation of input's component which includes: athletes' condition, coaches' condition, and support of agency in the Tennis Team of Bangka Belitung Province obtained an average value of $65.63 \%$. Overall, with an average score of $65.63 \%$ indicates that the evaluation of the input's component for coaching program of Tennis Team of Bangka Belitung Province in PON XIX West Java 2016 is included in the category enough (56\% - 65\%). So it can be concluded that the evaluation component contained in this stage of input is considered quite in accordance with the implementation of the caoching program of Tennis Team of Bangka Belitung Province in PON XIX West Java 2016.

Based on the results of context evaluation obtained which includes the purpose and planning strategy of coaching program of Tennis Team of Bangka Belitung Province have a relationship with the results of input evaluation obtained. This is in accordance with the opinion of Wirawan (2011: 93) that input evaluation is to find answers to the question "What to do?", this evaluation identifies issues, assets, and opportunities to help decision-makers identify objectives, priorities and helps broader groups of users to assess the objectives, priorities, and benefits of the program, assess alternative approaches, action plans, staff plans and budgets for feasibility and potential cost effectiveness to meet targeted needs and objectives.

Evaluation of input's component also got enough value with the implementation of coaching program of Tennis Team of Bangka Belitung Province in PON XIX of West Java 2016. Context's component which include: planning objectives and strategy (organization of tennis team, availability of supporting facilities and infrastructures the process of coaching, the process of athlete's recruitment, the process of coach's recruitment, and the availability of financing) indirectly affect the 1) Condition of athletes, 2) Condition of coaches, 3) Support of agency in coaching program of Tennis Team of Bangka Belitung Province in PON XIX West Java 2016.

3. Component of Process in Coaching Program of Tennis Team of Bangka Belitung Province in PON XIX West Java 2016

a) Implementation of Coaching Program in Tennis Team of Bangka Belitung Province in PON XIX West Java 2016

Based on implementation of coaching program in Tennis Team of Bangka Belitung Province in PON XIX West Java, West Java 2016, the coaching program system in Pelatda's team of Bangka Belitung Province in PON XIX West Java 2016 obtained value of 0\%. Overall, with an average score of $0 \%$ indicates that the coaching program system in Tennis Team of Bangka Belitung Province in PON XIX West Java 2016 is included in the category of very less (- 40\%). 
The promotion and degradation system in Pelatda's of Bangka Belitung Province in PON XIX West Java Year 2016 has been running, only on the tennis sports that did not go well. This happened because the quota of tennis's athletes is little, the ability of athletes to be a coat is still far so that the coaching program of Tennis Team of Bangka Belitung Province in PON XIX West Java 2016 focused on four athletes that exist. Promotion and degradation of the coach is not enforced given because the lack of licensed coaches as, the athletes in the coaching program is their own athletes all this time.

b) Implementation of Training Program in Tennis Team of Bangka Belitung Province in PON XIX West Java 2016

Implementation of training program in Tennis Team of Bangka Belitung Province for PON XIX West Java 2016 obtained value $60 \%$. Overall, with an average score of $60 \%$ indicates that the implementation of training program in Tennis Team of Bangka Belitung Province for PON XIX West Java 2016 is included in the category of sufficient (56\% - 65\%). Exercise program that has not run in Tennis Team of Bangka Belitung Province in PON XIX West Java 2016 is application Sport Science and Technology (test and evaluation). Not yet applied the sports science, exercise program only runs potluck without the implementation of athletes ability test periodically. The ability of athletes is only seen based on the results of try out match.

Implementation try out already implemented, but still felt less. Try out is done when TC is centered already running. For the implementation of try in has not been applied because of the limitations of athletes who can be opponent at the time of the Pelatda's program. Besides try out and try in, athletes of Tennis Team of Bangka Belitung Province in PON XIX West Java 2016 also minimal follow the championship. The lack of participation in each championship, in addition to less than the flight hours, makes the athletes' rank or Peringkat Nasional PELTI (PNP) far in comparison to other areas.

In tennis, good ranking or PNP is important and be beneficial for athletes when competing in PON. Regulation of PON XIX Java West Java 2016 based on athletes's rank or PNP. A good ranking or PNP of athlete certainly avoids athletes meeting tough opponents in the preliminary round. This is experienced by Tennis Team of Bangka Belitung Province in PON XIX West Java 2016 from the four athletes who have only one athlete who has the best PNP that is ranked 50. Therefore during the coaching program of Pelatda, the quantity try out and athletes' participation in events like national championship and open tournament can run simultaneously. So indirectly increase the rank or PNP of the athletes.

Based on the evaluation of the whole process which includes: implementation of coaching and training program, process evaluation obtained an average value of $42.86 \%$. Overall, with an average score of $42.86 \%$ indicates that the evaluation of process in coaching program of Tennis Team of Bangka Belitung Province in PON XIX West Java 2016 included into the category less (40\%-55\%). Then it can be concluded that evaluation components in this stage of the process is considered insufficient in the implementation of the coaching Program of Tennis Team of Bangka Belitung Province in PON XIX West Java 2016.

The existence of some indicators that have not run on the evaluation of context and input will have an effect on the result of process evaluation. Some factors that have not influenced the results of the process are: 1) Context Evaluation: there is no clear target achievement for the tennis teams of Bangka Belitung Province in facing PON XIX West Java 2016; 2) Input evaluation: there has been no guidance for the guidance of the teams of coaches, education and certification of coaches, the availability of training facilities or equipment needs to be improved, the procedure for recruiting the athletes is considered less, availability of financing in coaching 
program, athletes have not been selected based on physical, skill, health, and psychological tests, financing also still depends entirely on government budgets or APBD.

Based on the above, there are several implementation plans that have not run, so that affect the program. According to Stufflebeam (2007) explained that the evaluation process assesses the implementation of the plan to assist in conducting activities, then interpret the results. Evaluation component found in this process stage is considered less in the implementation of coaching program of Tennis Team of Bangka Belitung Province in PON XIX West Java 2016 due to limited number of tennis athletes who meet the criteria, making Pelatda's Tennis Team of Bangka Belitung Province in the facing PON XIX Java West 2016 consists of only one or a single layer. Unstructured training program and not yet applied ScienceScience and Technology. In the training program, try out is done limited number. Athletes onlu have a chance to participate in a local or regional championship (such as Sumatera's Championship), not yet participating in national or super series championships.

4. Component of Product in Tennis Team Tennis Pelatda Province of Bangka Belitung Province in PON XIX West Java 2016

a) Individual Results of Tennis Team of Bangka Belitung Province in PON XIX West Java 2016

For individual result, Tennis Team of Bangka Belitung Province in PON XIX West Java 2016 obtained an average value of $40 \%$. Overall, with an average score of $40 \%$ indicates that the individual results in the coaching program of Tennis Teams of Bangka Belitung Province in PON XIX West Java 2016 included less category (40\% - 55\%).

Of course, the success of tennis' athletes of Bangka Belitung Province successfully qualify for Pre PON become a big momentum for the development of tennis sport in Bangka Belitung Province. Bangka Belitung Province is one of the provinces that represented tennis sports from 10 provinces in the islands of Sumatra. This momentum should be a motivation in the implementation of Pelatda program development so as to get achievement in the event of PON XIX 2016 in West Java. Individual numbers consisting of men's singles and men's doubles are only able to reach the last 16 .

b) Team Results of Tennis Team of Bangka Belitung Province in PON XIX West Java 2016

For team results, Tennis Team of Bangka Belitung Province in PON XIX West Java 2016 obtained an average value of $0 \%$. Overall, with an average score of $0 \%$ indicates that the team result of coaching program of Tennis Team of Bangka Belitung Province in PON XIX West Java 2016 is categorized less (below 40\%).

The results of coaching program of Tennis Team of Bangka Belitung Province for team numbers get very less $(0 \%)$. Based on the target setting that only want to escape the top of 8 , but only until the top of 16. Weakness in targeting makes the athlete's motivation in the pelatda program to be reduced. The target should be maximized so that the training program can adjust to the achievement of the target. The team numbers themselves are not targeted, only limited to participating in the implementation of PON, so only until the preliminary round.

Based on the results of the overall product evaluation that includes: the individual and the team results in coaching program of Pelatda's tennis team of Bangka Belitung Province obtained an average value of $28.58 \%$. Overall, with an average score of $28.58 \%$ indicates that the evaluation of product for caoching program of Pelatda's tennis team of Bangka Belitung Province in PON XIX West Java included into the category is very less (below 40\%). So it can be concluded that 
the evaluation for component of product is considered not in accordance with the implementation of coaching program of Tennis Team of Bangka Belitung Province in PON XIX West Java 2016.

There are some indicators that have not run on the evaluation of context, input, and process affect the final result. Several factors that contribute to the outcomes of the coaching program of Tennis Team of Bangka Belitung Province in PON XIX West Java 2016 are: 1) Athletes and coaches' recruitment procedures, coaching systems and training programs that have not run maximally; 2) Quota of athletes that have little and the ability of athletes to become coating there is a gap that is still far away; 3) The lack of participation in every championship, in addition to less than the flight hours, makes the athlete's rank or PNP far in comparison to other areas so it is influential in the athletes when competing on the PON. The regulation of PON XIX of West Java 2016 based on athletes' ranking or PNP, only one of four athlete who has the best PNP that is ranked 50. Good rank or PNP of the athletes certainly avoid athletes meet hard opponents in the early round. But in fact, unlucky in drawing makes they directly meeting the leading teams like East Java Team and West Java Team at the first time.

\section{CONCLUSION}

1. Evaluation's component of context (which include goals and planning strategy) in coaching program of Tennis Team of Bangka Belitung Province in PON XIX West Java 2016 from 27 aspect of appraisal got an average value 59,26\%. Overall, with an average score of $59.26 \%$ indicates that the evaluation of context in caoching program of Tennis Team of the Bangka Belitung Province in PON XIX West Java 2016 is included in the category of sufficient (56\% $65 \%)$.

2. Evaluation's component of input (including condition of athletes, condition of coaches, and support of agency) in coaching program of Pelatda's teams tennis team of Bangka Belitung Province in PON XIX West Java Year 2016 from 32 assessment aspect obtained the average value 65,63\%. Overall, with an average score of $65.63 \%$ indicates that the evaluation of input in coaching program of Tennis Team of Bangka Belitung Province in PON XIX West Java 2016 is included in the category enough $(56 \%-65 \%)$.

3. Evaluation's component of process (which includes the implementation of coaching and training program) in Tennis Team of Bangka Belitung Province in PON XIX West Java 2016 from 14 aspects of the assessment obtained an average value of $42.86 \%$. Overall, with an average score of $42.86 \%$ indicates that the evaluation of process in coaching program of Tennis Team of Bangka Belitung Province in PON XIX West Java 2016 is included in the category of less (40\% - 55\%).

4. Evaluation's component of product (which includes result of implementation of coaching and training program) in Tennis Team of Bangka Belitung Province in PON XIX West Java 2016 both on individual and team number, from 7 aspect of appraisal, the average score is $28,58 \%$. Overall, with an average score of $28.58 \%$ indicates that the evaluation of product in coaching program of Tennis Team of Bangka Belitung Province in PON XIX West Java 2016 included into the category is very less (below 40\%).

Based on the results of the evaluation's component above, the coaching program of Tennis Team of Bangka Belitung Province in PON XIX West Java Year 2016 overall obtained value of $56.25 \%$. So it can be concluded that the coaching program of Tennis Team of Bangka Belitung Province in PON XIX West Java 2016 is considered sufficient. This program needs improvements in the aspects of the athlete and coach recruitment procedures, coaching systems and training programs for Pelatda's coaching program in the future Pekan Olahraga Nasional (upcoming PON). 


\section{REFERENCES}

Ann W. Frye and Paul A. Hemmer.(2012). Program Evaluation Models and Related Theories. AMEE

Guide No. 67, Medical Teacher.

Djaali and Pudji Mujiono.(2008). Measurement in the Education Sector. Jakarta: Grassindo.

Farida Yusuf Tayibnapis.(2006). Program Evaluation. Jakarta: Rieneka Cipta.

James Tangkudung.(2012). Sports Coaching. Jakarta: Smart Jaya,

Leigh Deves.(2012) Program Evaluation in Co-operative Education: A Dearth of Standards. AsiaPacific Journal of Cooperative Education. Vol.12, No. 3.

Matt Vassar, Denna L. Wheeler, Machelle Davison, (2010). Evaluation in Medical Education: An

Overview of the Utilization-focused Approach. Journal of Educational Evaluation for Health Professions. Vol.7, No. 1.

M. Sukardi.(2007). Educational Evaluation: Principles and Operations. Jakarta: Earth Script,

R. Lance Hogan.(2007). The Historical Development of Evaluation Program: Exploring the Past and Present. Online Journal of Workforce Education and Development. Vol.2, No. 4.

Suharsimi Arikunto and Cepi.(2009). Evaluation of Education Program: Practical Theoretical Guidance for Students and Education Practitioners. Jakarta: Earth Script.

Paul Ford, Mark De Ste Croix.(2011).The Long-Term Athlete Development Model: Phsyiological Evidence and Application. Journal of Sports Sciences, Vol.29, No . 4.

Wirawan,(2010). Evaluation. Theory, Model, Standard, Application and Profession. Jakarta: Raja Grafindo Persada. 